\title{
3.ウイルスの複製と伝播 植物ウイルスの移行タンパク質
}

\author{
渡辺雄一郎
}

(帝京大学理工学部)

\section{細胞間移行とは何か}

植物ウイルス遺伝子の塩基配列の決定が進む中で, 構造遺伝子, 複製に関与する遺伝子はゲノム上で対応 づけられるが発現や機能が定かでない open reading frame が見いだされることが多い。例えば夕バコモザ イクウイルス (TMV) の場合, 複製酵素である $180 \mathrm{~K}$

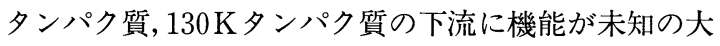
きさ $30 \mathrm{kDa}$ のタンパク質がコードされていた。このタ ンパク質の機能に関して情報を与えたのが，TMVの 温度感受性变異体 Ls 1 であった。野性型の TMV を Xanthi-nc, Samsun-NN などの夕バコに接種し， 2 日間 $23^{\circ} \mathrm{C}$ おいたうえで, 2 日間 $32^{\circ} \mathrm{C}$, 次にもう一度 2 日間 $23^{\circ} \mathrm{C}$ に戻すとかなり広がった壊疸病斑を形成す $3^{20)}$ 。一方Ls 1 は, 同じ操作で小さな広がりの病斑し かみせない。この Ls 1 はプロトプラストへの感染実 験では野性株と同等の複製を示すことから ${ }^{20)}$, Ls 1 は 複製は正常だが $32{ }^{\circ} \mathrm{C}$ という非許容温度ではウイルスが 周囲に広がることが出来ない, 細胞間移行に関する温 度感受性变異体と解釈された ${ }^{20)}$ 。ここで植物ウイルス が感染細胞から周囲の細胞に広がる過程を特に細胞間 移行と呼ぶ。この Ls 1 の $30 \mathrm{~K}$ タンパク質のアミノ配 列を調べると, 154番目のプロリンがセリンに変化して いることが明らかとなった(図 1) ${ }^{21)}$ 。人為的に野性型 の $30 \mathrm{~K}$ タンパク質の154番目のプロリンをセリンに変 異してやると, 実際, Ls 1 と同様に細胞間移行につい て温度感受性ウイルスとなり, $30 \mathrm{~K}$ タンパク質が細胞 間移行に関与していることが証明された ${ }^{15)}$ 。

Movement proteins of plant viruses Yuichiro Watanabe

Department of Biosciences Teikyo University,

Toyosato-dai 1-1, Utsunomiya 320

厂320 栃木県宇都宮市豊郷台 $1-1$
植物ウイルスの感染は, 自然界では, 葉, 茎, そし て根における傷から，または多くは昆虫による媒介に よって植物体に侵入する。点への感染がまずあって, そこから面への感染, 周囲の細胞へと 2 次元的に広が る。その際に $30 \mathrm{~K}$ タンパク質が機能しているのである。 人工的に $30 \mathrm{~K}$ タンパク質を削った TMVを解析する とプロトプラストでの複製能には影響がないが, 細胞 間移行能を失ったウイルスとなる ${ }^{15)}$ 。こによって 30 Kタンパク質は複製には関与していないことも示され た。現在では他のウイルスでも細胞間移行に関与する タンパク質が存在することが証明されつつある。この ことから TMV の $30 \mathrm{~K}$ タンパク質, さらには他のウイ ルスでも機能的に同等なタンパク質を移行タンパク質 (movement protein) と呼ぶ。

トマト壞疸病斑ウイルス (TSWV) について最近全 ゲノム構造が明らかとなった。このウイルスはゲノム 構造からも動物ウイルスのブンヤウイルスに非常に似 ている。ただ一箇所，ブンヤウイルスにないタンパク 質（Nsm）をコードする領域が TSWVのゲノム内に 見いだされた。このタンパク質は Goldbachのグルー プの知見から，まさにこのウイルスの細胞間移行に関 与する移行タンパク質であることが示唆されてい る11a)。

この細胞間移行に関する機能は異種のウイルス間で 相互に相補する例が示されている。例えば, 先の Ls 1 株は $32^{\circ} \mathrm{C}$ で単独に植物体に広がることは不可能である が, ポテトウイルスX (PVX) と同時に感染させると

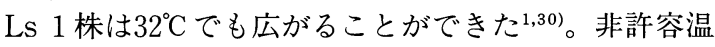
度でも異なるウイルスによって移行タンパク質の機能 が補われたものと思われる。ブロムモザイクウイルス (BMV) は通常トマトでは広がらないが，トマト系 TMV と混合感染すると広がること, 宿主域が乗り越 えられることが示されている（これによって移行蛋白 


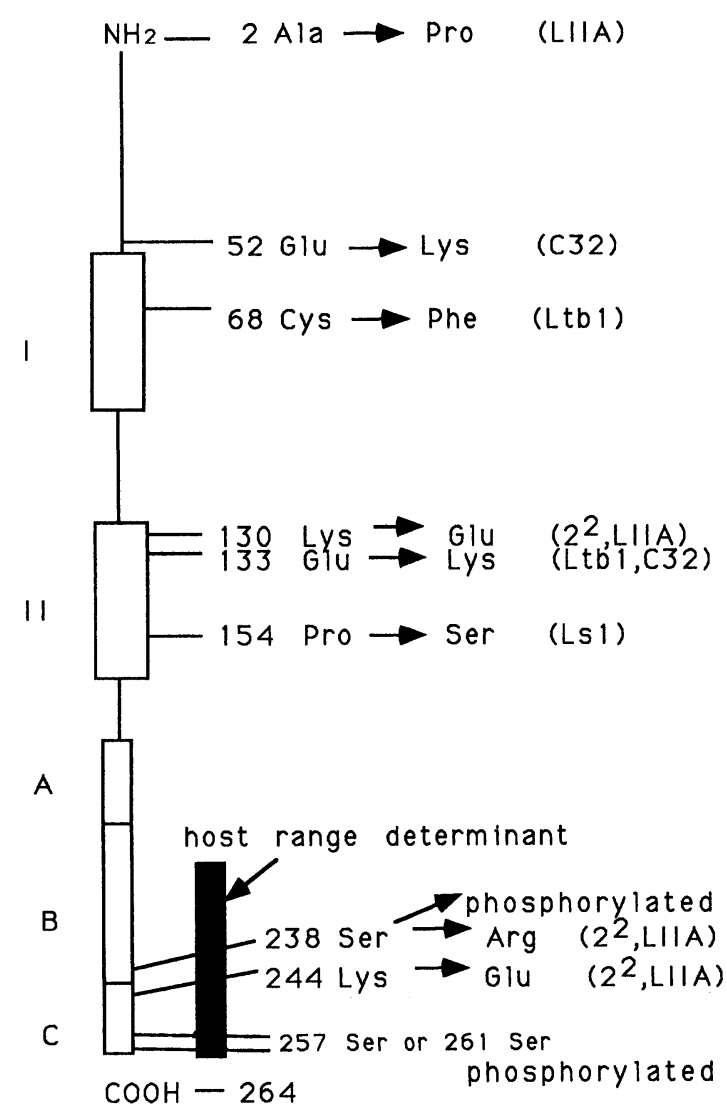

図 1 トマト系タバコモザイクウイルス (TMV) の30 Kタンパク質（移行タンパク質）に関する情報。 全264アミノ酸からなる。種々のTMVの株の30 $\mathrm{K}$ タンパク質を比較して，アミノ酸の一次構造 上保存性の高い領域をboxで示している27)。Ls1, $\mathrm{L}+\mathrm{b} 1 ， 2^{2}$ に関しては本分参照。

質が宿主域決定因子として機能することも示された。 後述) ${ }^{1,29)}$ 。また, TMV 抵抗性 Tm-2遺伝子 (後述)を 持ったトマトでは TMVの細胞間移行が阻害される が，PVX と同時に感染させると TMV は広がること ができる1,29)。

\section{原形質連絡への局在}

このように植物ウイルスであるゆえの機能を担う移 行タンパク質であるが，どのようにして機能している かが，未知である。我々は TMV の $30 \mathrm{~K}$ タンパク質の C末に対応する 16 アミノ酸残基からなる人工ペプチド による抗体作成を行った ${ }^{22)}$ 。反応性, 特異性を確認し, $\mathrm{TMV}$ 感染植物の試料に対し金コロイド法による免疫
電子顕微鏡観察を行った ${ }^{31)}$ 。その結果, 植物体ではとな りあった細胞同志をつなげる構造と知られる原形質連 絡 ${ }^{26)}$ に局在していることが明らかとなった ${ }^{31)}$ 。植物ウ イルスはとなりあった細胞へと移行する際，原形質連 絡を経由するので，移行タンパク質の機能からして， となりあった細胞間をつなぐ原形質連絡への局在は結 果としてうなづける。ちなみに, 最近 Lucas と Beachy は，30kD 蛋白質が局在するのは主に伸長を終えた組 織に見られる分岐構造を持つ“二次” 原形質連絡であ って，若い組織に存在する直線状の “一次” 原形質連 絡には見いだされないといっている7,19)。原形質連絡と いっても全ては同じものでないことは念頭におく必要 があろう。

移行タンパク質について同様の局在が示されている ウイルスとしてカリフラワーモザイクウイルス (CaMV) の遺伝子 $1^{13)}$ ，アルファルファモザイクウ イルス(AIMV)のP $3^{10)}$, red clover necrotic mosaic virus (RCNMV) の35-kDa タンパク質23)などがある。 少し局在性が異なると報告されたものにはPVX の 25 $-\mathrm{kDa}$ タンパク質 (細胞質の封入体構造 $)^{4 \mathrm{a})}$ ，キュウリ モザイクウイルス (CMV) の $3 \mathrm{a}$ タンパク質 (核) ${ }^{14)}$ がある。この違いは，同じ移行蛋白質でも働き方が異 なることを意味するのであろうか。

ササゲモザイクウイルス (CPMV) の移行タンパク 質として58- $\mathrm{kD}$ と 48-kD タンパク質が同定されてい る ${ }^{32)}$ 。このウイルスが感染した植物では原形質連絡に ウイルス粒子を含む形の管状構造が認められる ${ }^{32) 。 フ ゚ ~}$ ロトプラストにこのウイルスを感染させ，12-21時間 もすると実は細胞膜に包まれたこの構造がプロトプラ ストの表面から突出してくる。この構造には58-kD と 48-kD タンパク質，コートタンパク質が局在する ${ }^{11)}$ 正常な48- $\mathrm{kD}$ タンパク質が合成できない変異体では この構造が形成されないこと，さらには48-kD タンパ ク質のみが発現するように形質導入された植物でもこ の構造が形成されることから $48-\mathrm{kD}$ タンパク質がこ の構造の形成に関与する ${ }^{36)}$ ことが証明された。CaMV の遺伝子 ${ }^{24)}$, TSWV の NSm 遺伝子についてもこの 管状構造が観察されている。TMVの場合,このような 構造は見いだされていない。細胞間移行にウイルスコ ートタンパク質が必要なウイルスで管状構造が見いだ されているので，その差によるかも知れない。そのか わり, TMVの場合, $30 \mathrm{~K}$ タンパク質単独でゲノム RNA と会合してコンパクトな構造を形成し ${ }^{4)}$, 細胞間 移行に寄与することが示唆されている (後述)。 


\section{原形質連絡を広げる}

原形質連絡は通常分子量800以下の分子の流通を妨 げないが，それ以上の大きさの分子に対しては障壁と なることが知られていた ${ }^{26)}$ 。植物ウイルスは原形質連 絡を経由する以上，この物理的な問題を解決しなけれ ばならない。どのようにしているのであろうか。TMV の移行タンパク質を構成的に発現する形質転換体植物 が作成され(5)，その性質がいろいろな形で解析されて いる。このような植物でも移行タンパク質は原形質連 絡に局在している。Roger Beachy と Bill Lucasのグ ループは以下のような細胞学的な実験を行った ${ }^{37) 。 ~}$ FITC ラベルされたデキストランを海綿状葉肉細胞の 細胞間を（原形質連絡を介して）移行するかを特殊な 蛍光顕微鏡によって観察した。その結果, 通常の夕バ コでは分子量800以下のデキストランを通すに過ぎな いものが， $30 \mathrm{~K}$ タンパク質を構成的に発現する夕バコ “277”では分子量約 10000 程のもの（2.4nm ほどのス トークス半径) まで通ることが示された ${ }^{37)}$ 。 $30 \mathrm{kD}$ 蛋白 質が原形質連絡の “穴”を広げているのは事実のよう である。Ls 1 (許容温度 $24^{\circ} \mathrm{C} /$ 非許容温度 $32^{\circ} \mathrm{C}$ ) の 30 $\mathrm{kD}$ 蛋白質を構成的に発現する形質転換体を $32^{\circ} \mathrm{C}$ に 6 時間以上おいた場合, 上で述べた穴の広がりは観察さ れない。逆にこの後 $24^{\circ} \mathrm{C}$ に温度を戻し 6 時間以上おい た場合, 再び穴が広がったことが確認される38)という。 この時 $30 \mathrm{kD}$ 蛋白質自身の局在性には变化はないの で，蛋白質自身の構造変化によって原形質連絡の穴の 大きさが 6 時間で可逆的に変化したことを示してい る ${ }^{38)}$ 。AIMV で同様の観察 ${ }^{25)}$ がなされている。

TMV と近縁で, 移行蛋白質の機能が互換可能な夕 バコラットルウイルス (TRV) を用いた類似の実験が 報告された ${ }^{6)}$ 。Nicotiana clevelandii タバコの毛状突起 (trichome)の細胞に TRVを injectionした後, 時間 を追って種々の物質を再度 injectionし, 隣り合った細 胞へのその物質の広がりを追った。その結果, ウイル スを前もって 5 時間ほど前に injection した毛状突起 での実験に限り, 周囲の細胞へ分子量3000-4400程の 物質が広がることが確認された6)。分子量 10000 ほどの 物質では移行は認められない。ウイルスを前もって injectionしておくことが重要で，しかも経過時間が 2 時間ほどでは効果は認められない6)。ウイルス感染後 5 時間の増殖によって産出される移行蛋白質がこのよ うな効果をもたらしていると考えられる。ここで必要 となった経過時間は，我々は以前見いだした事実， TMV の $30 \mathrm{kD}$ 蛋白質が感染後 $2-8$ 時間に一過的に
発現することと符号する ${ }^{33)}$ 。

原形質連絡の穴を通る分子の大きさについては，原 形質連絡が存在する組織によって異なる事実がある。 師要素と伴細胞との間では $3 \mathrm{kDa}$ の大きさを持った 分子が透過できる報告もあり ${ }^{12)}$ ，一概に植物体全ての 原形質連絡の大きさがある大きさに広がるなどという 議論には危険性が伴う。

\section{核酸との結合能}

Zambryski らは TMV の移行蛋白質を大腸菌で大 量発現させたのち，精製をし，その生化学的な性質を 調べている。その中でこの蛋白質が一本鎖の核酸に協 同的 (cooperative) に結合する能力を持っていること を見いだした2)。核酸はDNA であっても RNA であっ ても結合し，その配列も問わないという。彼女らは， 移行蛋白質は一本鎖の核酸（細胞内では TMVの RNA を想定している) と結合して，原形質連絡に運ぶ などしてウイルスの細胞間移行を促進していると考え ている4)。

次に，移行蛋白質が一本鎖の核酸と結合して形成す る構造を電子顕微鏡で観察している ${ }^{4)}$ 。その結果, 長 く，折り畳まれたりせずに大変細い直径1.5-2.0nm というような構造体を見いだした4)。このようなもの が実際の感染細胞内でできれば, 先に紹介した感染 (ま たは移行蛋白質が発現している）細胞で大きくなった 原形質連絡の大きさ， $2.4 \mathrm{~nm}$ という空間を透過出来る であろう。我々はこれとは別にプロトプラストに $\mathrm{TMV}$ を感染させたのち,この $30 \mathrm{kD}$ 蛋白質が電子密度 の低い構造体（感染特異的）の中に局在することを認 めている ${ }^{17)}$ 。細かく見ると, その局在する場に紐状のも のが確認されることがあり，上で述べた核酸（期待さ れるのは TMV， RNA）と結合した状態の $30 \mathrm{kD}$ 蛋白 質, あるいは $30 \mathrm{kD}$ 蛋白質が原形質連絡に移行する前 の細胞質での存在様式をin vivo で見ている可能性が ある。

$\mathrm{RCNMV}$ の35-kD タンパク質についても同様の解 析結果が出されている ${ }^{9)}$ 。この例で一連のアミノ酸置 換変異体が作成され，それぞれの in vivo でのウイル スの細胞間移行能と in vitro での RNA 結合能との対 応が解析された。野性型と比べて RNA 結合能が $20 \%$, 25\%の変異体 "27-31”，“305”でも野性型なみの細胞 間移行能を示したのに対し, 逆に RNA 結合能が $109 \%$ と保持されている変異体 “278”ではウイルスの細胞間 移行能を失っていた 接ウイルスの細胞間移行能に関与するのではないこと 
を示す。

藤原らは蛍光色素をつけた RCNMV の35-kD タン パク質を植物体に injection し,このタンパク質が単独 で原形質連絡を透過して周囲の細胞へと広がること采 を報告している。核酸との結合と独立に細胞間移行す ることは興味深い。CaMV の遺伝子 $1^{3)}$, AIMVの 3 $\mathrm{a}$ 遺伝子 ${ }^{28)}$ についても核酸との結合能が報告されてい る。ただし，他のウイルスについては以上紹介したレ ベルの核酸との結合能について，私信，未発表デー夕 で否定的なものもあることを書き添えておく。

Geminivirus はDNA ウイルスである。A-component, B-component と呼ばれる二種類の DNA ゲノム をもつ。その B-component にコードされている BR 1 と BL1タンパク質について興味深いデータが, 最近 Bill Lucas らによって報告された20a)。植物細胞に前も つて蛍光色素をつけたDNA を injectionしておく。 DNA は核に集まるが，その時期にBRIをinjection するとDNA が細胞質に拡がることを見いだしたので ある。これは，このウイルスのゲノムが核で複製する ことと関連があると考えられる。BR1タンパク質のこ の性質は核で複製した子孫ウイルスゲノムを核から引 き出し, BL1タンパク質による細胞間移行,つまり次の 感染の準備をする目的にかなっている。BL1タンパク 質は今まで紹介した移行タンパク質の性質をもってい る20a)。ウイルスというのは考えようによっては遺伝子 であるゲノムの核酸を合成された場から次の場へとい かに移行させるか巧みなことをする存在である。以上 見てきたウイルス遺伝子産物と核酸との結合能という のはその基本となる性質なのかも知れない。

\section{宿主適応の因子/移行タンパク質の C末端近傍のアミノ酸配列}

この $30 \mathrm{kD}$ 蛋白質とウイルス抵抗性に寄与する宿主 因子, さらにある種のリン酸化酵素との相互作用があ ることが最近明らかとなり, 多彩な宿主とウイルスの 相互作用の様子が浮かびあがってきた。飯らによって, トマトの TMV 抵抗性遺伝子である Tm-2がいかに TMVの增殖を抑えるのかが解析された。野性株Lと 異なり，Tm-2遺伝子をもつトマトでも増殖可能とな ったLtb 1 株がまず単離され，その原因が調べられ た ${ }^{16)}$ 。その結果, Ltb 1 株は $30 \mathrm{kD}$ 蛋白質のの中にアミ ノ酸の置換変異 2 個 (Cys68 $\rightarrow$ Phe, Glu133 $\rightarrow$ Lys, 困 1 参照)をもつことにより，Tm-2トマトでも増殖可能 となったこと年が明らかとなった。まだ単離されてお らずその実体は明らかではないが Tm-2遺伝子産物は
原形質連絡に存在する何らかの蛋白質で，野性株の 30 $\mathrm{kD}$ 蛋白質に阻害的に作用するために抵抗性を示すの ではないかと考えられる。Ltb 1 株の $30 \mathrm{kD}$ 蛋白質では その作用を受けない形に変異をしているのであろう。

Weber ${ }^{35)}$, 池田らは, 同様にトマトの TMV 抵抗性 遺伝子である $\mathrm{Tm}-2^{2}$ と TMV との相互作用のメカニ ズムを解析した。 $\mathrm{Tm}-2^{2}$ 遺伝子をもつトマトでも增殖 可能となった $2^{2}$ 株が材料となった。Ltb 1 株と同様の 解析の結果， $2^{2}$ 株は $30 \mathrm{kD}$ 蛋白質の中にアミノ酸の置 換変異 3 個（図 1 参照）があることにより, Tm-2 マトでも増殖可能となったことが明らかとなった。こ れらのうち, 後ろの変異 2 個 (Ser238 $\rightarrow$ Arg, Lys244 $\rightarrow \mathrm{Glu}$, 図 1 参照) が抵抗性を打ち破るのに重要である ことが判ってきた。図1を見ると Tm-2遺伝子，Tm$2^{2}$ 遺伝子産物と相互作用する $30 \mathrm{kD}$ 蛋白質の領域が異 なることがわかる。 $\mathrm{Tm}-2$ 遺伝子, $\mathrm{Tm}-2^{2}$ 遺伝子は相互 に遺伝学的には allelic であるので宿主遺伝子産物と 移行蛋白質との相互作用を考える上で興味深い事実で ある。

C 端の50-70アミノ酸残基の領域が宿主特異性を決 定している例が報告されてきたので次に紹介する。the Scripps Research Instituteの Curtis Holt, Csilla Fenczik らは以下の現象を見いだした。TMVの普通 系は夕バコには感染するが, 単子葉植物であるランで は感染は成立しない。ORSV は同じトバモウイルスで あるが，ランには感染し，タバコには感染しない。普 通系のゲノム上, 移行タンパク質 (268アミノ酸残基) のみを ORSVのもの (280アミノ酸残基)に交換しただ けでその人工ウイルス (TMV-OMP) は，タバコには 感染することが出来なくなり, 逆にランで感染可能と なった。この系で移行タンパク質が宿主決定因子であ ることになる。人工ウイルスを夕バコに接種し，長期 にわたって維持するとなかで病原性を獲得して現れた ウイルスが 2 種類見いだされた。それらのウイルスの 移行タンパク質の構造を紹介すると図 2 のようになっ ていた。一つは280アミノ酸残基の ORSV 移行タンパ ク質の ORF が途中 223 アミノ酸残基のところで終結 するようになったもの $(\mathrm{MzL})$ ，もう一つは ORSV 移 行タンパク質の ORF が途中186アミノ酸残基まで続 いた後, 普通系の移行タンパク質の187-268番目のア ミノ酸残基が一つの融合移行タンパク質として合成さ れるようなウイルス $(\mathrm{V}-1)$ となっていた。これらの事 実は, 移行タンパク質の C 端約50-60アミノ酸残基は 存在することで本来宿主といわれる植物での病原性が 現れる。一方, 非宿主の植物ではその配列を持つこと 


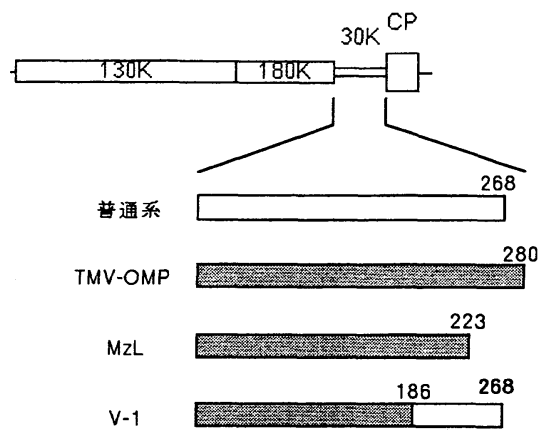

\begin{tabular}{|c||c|}
\hline $\begin{array}{c}\text { Nicotiana } \\
\text { tabacum }\end{array}$ & $\begin{array}{c}\text { Vanilla } \\
\text { planifolia } \\
\text { (ランの一種) }\end{array}$ \\
\hline $\mathrm{S}$ & $\mathrm{L}$ \\
\hline $\mathrm{L}$ & $\mathrm{S}$ \\
\hline $\mathrm{S}$ & $\mathrm{L}$ \\
\hline $\mathrm{S}$ & $\mathrm{NT}^{*}$ \\
\hline
\end{tabular}

図 2 移行タンパク質の交換, 变化に伴う宿主域の変化。S は全身感染, L は局所的に 感染するのみを意味する。NT は現在実験中, 予備的なデータではLである。

はかえってマイナスとなり，失失した方が適応できる と解釈される(図 2 )。

brome mosaic virus（BMV) はオオムギを宿主と する。cowpea chlorotic mosaic virus (CCMV) は ササゲを宿主とする。三瀬らは移行タンパク質の $3 \mathrm{a}$ 領域を相互に交換すると，宿主域が見事に逆になるこ とを示した ${ }^{18)}$ 。CCMVのゲノム上 $3 \mathrm{a}$ 領域のみを BMVの 3 a 領域と交換するとオオムギで病原性を発 揮するが, ササゲでは発揮できなくなる ${ }^{18)}$ 。この場合も ササゲに接種し長時間待つとなかに病気が現れること がある。そのウイルスのゲノムを調べると，中に入れ た $3 \mathrm{a}$ 領域のアミノ酸配列の中に置換が起きていた。 この例も移行蛋白質の宿主域決定への関与を示してい る。

最近, 我々は TMV の $30 \mathrm{kD}$ 蛋白質が植物細胞内で リン酸化を受けていることを確認した ${ }^{34)}$ 。ホスホアミ ノ酸分析すると，セリンがリン酸化を受けていた。次 に 1 -233番目のアミノ酸残基からなる移行蛋白質で はリン酸化を受けないが 1 -261番目からなる移行蛋 白質, 10-141番目のアミノ酸残基を欠失した移行蛋白 質ではリン酸化を受けることが確認された。リン酸化 をうける部位が $30 \mathrm{kD}$ 蛋白質のうち C 端に近い約 30 ア ミノ酸残基にあることが推測される。

宿主のウイルス抵抗性や宿主域決定の現象はこの領 域のリン酸化の度合を含めて移行タンパク質と宿主側 因子との相互作用を考える必要がありそうである。

\section{最 後に}

植物ウイルスの細胞間移行に始まり, 宿主域決定, ウイルス抵抗性の現象に至るまで, 移行タンパク質と
いうものを紹介してきた。移行タンパク質についての 研究はウイルス学はもちろん, 細胞学, 遺伝学, 育種 学, タンパク質の構造解析など関係分野が多岐にわた り，それだけにおもしろい情報を与えてくれている。 今後, これらの分野間の交流, 研究者同志の情報交換, 共同研究によって分子の言葉でこれらの現象がより詳 細に記述されることを願うものである。

\section{文献}

1) Atabekov, J. G., Dorokhov, Y. L. : 1984. Plant virus-specific transport function and resistance of plants to viruses, Adv. Virus Res., 29, 313-364

2) Citovsky, V., Knorr, D., Schuster, G., Zambryski, P. : 1990. The P30 movement protein of tobacco mosaic virus is a single-strand nucleic acid binding protein, Cell, 60, 637-647

3) Citovsky, V., Knorr, D., Zambryski, P. : 1991. Gene I, a potential cell-to-cell movement locus of cauliflower mosaic virus, encodes an RNA-binding protein, Proc. Natl. Acad. Sci. USA, 88, 2476-2480

4) Citovsky, V., Wong, M. L., Shaw, A. L., Venkataram Prasad, B. V., Zambryski, P. : 1992. Visualization and charaterization of tobacco mosaic virus movement protein binding to single-stranded nucleic acids, Plant Cell, 4, 397-411

4a) Davies, C., Hills, G., Baulcombe, D. C. : 1993. Subcellular localization of the $25-\mathrm{kDa}$ protein encoded in the triple gene block of potato virus X, Virol., 197, 166-175. 
5) Deom, C. M., Oliver, M. J., Beachy, R. N. : 1987. The 30-kilodalton gene product of tobacco mosaic virus potentiates virus movement., Science, 237, 289-394

6) Derrick, P. M., Barker, H., Oparka, K. J. : 1992. Increase in plasmodesmatal permeability during cell-to-cell spread of tobacco rattle virus from individually inoculated cells, Plant Cell, 4, 1405-1412

7) Ding, B., Haudenshield, J. S., Hull, R. J., Wolf, S., Beachy, R. N., Lucas, W. J.: 1992. Secondary plasmodesmata are specific sites of localization of the tobacco mosaic virus movement protein in transgenic tobacco plants, Plant Cell, 4, 915-928

8) Fujiwara, T., Giesman-Cookmeyer, D., Ding, B., Lommel, S. A. and Lucas, W. J. : 1993. Cell-to-cell trafficking of macromolecules through plasmodesmata potentiated by the red clover necrotic mosaic virus movement protein, Plant Cell, 5, 17831974

9) Giesman-Cookmeyer, D. and Lommel, S. A. : 1993. Alanine scanning mutagenesis of a plant virus movement protein identifies three functional domains, Plant Cell, 5, 973-982

10) Godefroy-Colburn, T., Gagey, M. -J., Berna, A. and Stussi- Garaud, C. : 1986. A non-structural protein of alfalfa mosaic virus in the walls of infected tobacco cells, J. Gen. Virol., 67, 2233-2239

11a) Kormelink, R., storms, M., Van Lent, J., Peters, D., Goldbach, R. : 1994. Expression and subcellular location of the $\mathrm{NS}_{\mathrm{M}}$ protein of tomato spotled wilt virus (TSWV), a putative viral movement protein, Virol., 200, 56-65.

11) Kasteel, D., Wéllink, J., Verver, J., van Lent, J., Goldbach, R. and van Kammen, A. : 1993. The involvement of cowpea mosaic virus M RNA-encoded proteins in tubule formation, J. Gen, Virol., 74, 1721-1724

12) Kempers, R., Prior, D. A. M., Van Bel, A. J. E. and Oparka, K. J. : 1993. Plasmodesmata between sieve element and companion cell of extrafascicular stem phloem of Cucurbita maxima permit passage of $3 \mathrm{kDa}$ fluorescent probes, Plant J., 4, 567-575

13) Linstead, P. J., Hills, G. J., Plaskitt, K. A., Wilson, I. G., Harker, C. L. and Maule, A. J. : 1988. The subcellular location of the gene I product of cauliflower mosaic virus is consistent with a function associated with virus spread, J. Gen. Virol., 69, 1809-1818
14) Mackenzie, D. J. and Tremaine, J. H. : 1988. Ultrastructural location of non-structural protein 3a of cucumber mosaic virus in infected tissue using monoclonal antibodies to a cloned chimeric fusion protein, J. Gen. Virol., 69, 2387-2395

15) Meshi, T., Watanabe, $Y .$, Saito, T., Sugimoto, A., Maeda, T., Okada, Y. : 1987. Function of the $30 \mathrm{kd}$ protein of tobacco mosaic virus : involvement in cell-to-cell movement and dispensabillty for replication, EMBO J., 6, 2557-2563

16) Meshi, T., Motoyoshi, F., Maeda, T., Yoshiwoka, S., Watanabe, H., Okada, Y. : 1989. Mutations in the tobacco mosaic virus $30-\mathrm{kD}$ protein gene overcome $\mathrm{Tm}-2$ resistance in tomato., Plant Cell, 1, 515-522

17) Meshi, T., Hosokawa, D., Kawagishi, M., Watanabe, Y., Okada, Y. : 1992. Reinvestigation of intracellular localization of the $30 \mathrm{~K}$ protein in tobacco protoplasts infected with tobacco mosaic virus RNA, Virol., 187, 809813

18) Mise, K., Allison, R. F., Janda, M., Ahlquist, P. : 1993. Bromovirus movement protein genes play a crucial role in host specificity, J. Virol., 67, 2815-2823

19) Moore, P. J., Fenczik, C. A., Deom, C. M. and Beachy, R. N. : 1992. Developmental changes in plasmodesmata in transgenic tobacco expressing the movement protein of tobacco mosaic virus, Protoplasma, 170, 115127

20) Nishiguchi, M., Motoyoshi, F., oshima, N. : 1978. Behavior of a temperature-sensitive strain of tobacco mosaic virus in tomato leaves and protoplasts., J. Gen. Virol., 39, 53-61

20a) Noueiry, A. O., Lucas, W. J., Gilbertson, R. L. : 1994. Two proteins of a Plant DNA virus coordinate nuclear and plasmodesmal transport, cell, 76, 925-932.

21) Ohno, T., Takamatsu, N., Meshi, T., Okada, Y., Nishiguchi, M., Kiho, Y. : 1983. Single amino acid substitution in $30 \mathrm{~K}$ protein of TMV defective in virus transport function, Virol., 131, 255-258

22) Ooshika, I., Watanabe, Y., Meshi, T., Okada, Y., Igano, K., Inouye, K., Yoshida, N. : 1984. Identification of the $30 \mathrm{~K}$ protein of TMV by immunoprecipitation with antibodies directed against a synthetic peptide., Virol., 132, 71-78

23) Osman, T. A. M. and Buck, K. W. : 1991. 
Detection of the movement protein of red clover necrotic mosaic virus in a cell wall fraction from infected Nicotiana clevelandii plants, J. Gen. Virol., 72, 2853-2856

24) Perbal, M. -C. : Thomas, C. L. and Maule, A. J. : 1993. Cauliflower mosaic virus gene I product $(\mathrm{P} 1)$ form tubular structures which extend from the surface of infected protoplasts, Virol., 195, 281-285

25) Poirson, A., Turner, A. P., Giovane, C., Berna, A., Roberts, K. and Godefroy-Colburn, T. : 1993. Effect of the alfalfa mosaic virus movement protein expressed in transgenic plants on the permeability of plasmodesmata, J. Gen. Virol., 74, 2459-2461

26) Robards, A. W. and Lucas, W. J. : 1990. Plasmodesmata, Annu. Rev. Plant Physiol. Plant Mol. Biol., 41, 369-419

27) Saito, T., Imai, Y., Meshi, T., Okada, Y. : 1988. Interviral homologies of the $30 \mathrm{~K}$ proteins of tobamoviruses., Virol., 167, 653-656

28) Schoumacher, F., Erny, C., Berna, A., Godefroy-Colburn, T. and Stussi-Garaud, C. : 1992. Nucleic acid-binding properties of alfalfa mosaic virus movement protein produced in yeast, Virol., 188, 896-899

29) Taliansky, M. E., Malyshenko, S. I., Pshennikova, E. S. and Atabekov, J. G. : 1982. Plant virus-specific transport function II. a factor controlling virus host range, Virol., 122, 327-331

30) Taliansky, M. E., Malyshenko, S. I., Pshennikova, E. S., Kaplan, I. B., Ulanova, E. Fand Atabekov, J. G. : 1982. Plant virus-specific transport function I. virus genetic control required for systemic spread, Virol., 122, 318 $-326$

31) Tomenius, K., Clapham, D., Meshi, T. : 1987. Localization by immunogold cytochemisty of the virus-coded $30 \mathrm{~K}$ protein in plasmodes- mata of leaves infected with tobacco mosaic virus, Virol., 160, 363-371

32) van Lent, J., Storms, M., van der Meer, F., Wellink, J. and Goldbach, R. : 1991. Tubular structures involved in movement of cowpea mosaic virus are also formed in infected cowpea protoplasts, J. Gen. Virol., 72, 26152623

33) Watanbe, Y., Emori, Y., Ooshika, I., Meshi, T., Ohno, T., Okada, Y. : 1984. Synthesis of TMV-specific RNAs and proteins at the early stage of infection in tobacco protoplasts: Transient expression of the $30 \mathrm{~K}$ protein and its mRNA, Virol., 133, 18-24

34) Watanabe, Y., Ogawa, T., Okada, Y. : 1992. In vivo phosphorylation of the $30-\mathrm{kDa}$ protein of tobacco mosaic virus, FEBS Lett., 313, 181-184

35) Weber, H., Schultze, S. and Pfitzner, A. J. P. : 1993. Two amino acid substitutions in the tomato mosaic virus 30 -kilodalton movement protein confer the ability to overcome the $\mathrm{Tm}^{-}$ $2^{2}$ resistance gene in the tomato, J. Virol. , 67, 6432-6438

36) Wellink, J., van Lent, J. W. M., Verver, J., Sijen, T., Goldbach, R. W. and van Kammen, A. : 1993. The cowpea mosaic virus M RNA-encoded 48-Kilodalton protein is responsible for induction of tubular structures in protoplasts, J. Virol., 67, 3660-3664

37) Wolf, S., Deom. C. M., Beachy, R. N., Lucas, W. J. : 1989. Movement protein of tobacco mosaic virus modifies plasmodesmatal size exclusion limit, Science, 246, 377-379

38) Wolf, S., Deom, C. M., Beachy, R., Lucas, W. J. : 1991. Plasmodesmatal function is probed using transgenic tobacco plants that express a virus movement protein, Plant Cell, 3, 593-604 